\title{
Neutrophils, eosinophils, and mast cells in the intestinal wall of dogs naturally infected with Leishmania infantum
}

\author{
Neutrófilos, eosinófilos e mastócitos na parede intestinal de cães naturalmente infectados \\ com Leishmania infantum
}

Diogo Tiago da Silva ${ }^{1,2}$; Maria Luana Alves ${ }^{1,2}$; Júlio Cesar Pereira Spada ${ }^{1,2}$; Rita de Cássia Viveiros da Silveira ${ }^{3}$; Trícia Maria Ferreira de Sousa Oliveira ${ }^{2,4}$; Wilma Aparecida Starke-Buzetti ${ }^{1 *}$

\begin{abstract}
${ }^{1}$ Departamento de Biologia e Ciência Animal, Faculdade de Engenharia de Ilha Solteira - FEIS, Universidade Estadual Paulista UNESP, Ilha Solteira, SP, Brasil

${ }^{2}$ Programa de Graduação em Epidemiologia Experimental Aplicada às Zoonoses, Universidade de São Paulo - USP, São Paulo, SP, Brasil

${ }^{3}$ Pós-doutorado, Instituto de Biotechnologia, Universidade Estadual Paulista - UNESP, Botucatu, SP, Brasil

${ }^{4}$ Departmento de Medicina Veterinária, Universidade de São Paulo - USP, Faculdade de Engenharia de Alimentos e Ciência Animal FZEA, Pirassununga, SP, Brasil
\end{abstract}

Received April 03, 2018

Accepted October 17, 2018

\begin{abstract}
Visceral leishmaniasis (VL) is a disease caused by the protozoa Leishmania infantum and can cause an inflammatory reaction in the gastrointestinal tract, however the role of granulocytic cells (neutrophils, eosinophils, and mast cells) in the intestine of dogs infected is not fully understood. We performed a quantitative analysis these cells in the intestinal wall of dogs with canine visceral leishmaniasis (CVL). Twenty dogs were assigned to one of three groups: group $1(\mathrm{G} 1, \mathrm{n}=8)$, dogs with CVL and L. infantum amastigotes in the intestine; group 2 (G2, n=9), dogs with CVL but without intestinal amastigotes; and group $3(\mathrm{G} 3, \mathrm{n}=3$ ), uninfected dogs (control group). Granulocytic cells were counted in the crypt-villus unit (mucosa), submucosa, and muscle layer of the intestinal mucosa. Cell counts were higher in the intestinal wall of dogs from G2 followed by G1 and G3 (p $\leq 0.05$ ). In G1, there was a low inverse correlation between parasite burden of the small intestine and granulocyte counts $(\mathrm{r}=-0.1, \mathrm{p} \leq 0.01)$. However, in $\mathrm{G} 2 \mathrm{dogs}$, mast cell and eosinophil numbers showed positive correlation $(\mathrm{r}=0.85, \mathrm{p} \leq 0.01)$. The granulocytic cell hyperplasia observed in the intestine of $L$. infantum-infected dogs suggests that these cells may be involved in the cell-mediated immune response for parasite elimination.
\end{abstract}

Keywords: Canine visceral leishmaniasis, intestinal tract, granulocytes.

\section{Resumo}

A leishmaniose visceral (LV) é uma doença causada pelo protozoário Leishmania infantum e pode causar uma reação inflamatória no trato gastrointestinal, entretanto o papel das células granulocíticas (neutrófilos, eosinófilos e mastócitos) no intestino de cáes infectados não é totalmente compreendido. Neste estudo realizamos uma análise quantitativa dessas células na parede intestinal de cães com LV. Vinte cães foram distribuídos em três grupos: grupo $1(\mathrm{G} 1, \mathrm{n}=8)$, cães com LV e amastigotas de L. infantum no intestino; grupo $2(\mathrm{G} 2, \mathrm{n}=9)$, cães com LV, mas sem amastigotas intestinais; e grupo 3 (G3, n=3), não infectados (grupo controle). Células granulocíticas foram contadas na unidade cripta-vilo (mucosa), submucosa e camada muscular da mucosa intestinal. Observamos hiperplasia dessas células na parede intestinal de cães do $\mathrm{G} 2$, seguidas das $\mathrm{G} 1$ em relação ao $\mathrm{G} 3(\mathrm{p} \leq 0,05)$. No $\mathrm{G} 1$, houve uma correlaçáo inversa baixa entre a carga parasitária do intestino delgado e a contagem de granulócitos $(\mathrm{r}=-0,1 ; \mathrm{p} \leq 0,01)$. No entanto, nos cáes do $\mathrm{G} 2$, os números de mastócitos e eosinófilos apresentaram correlaçáo positiva $(\mathrm{r}=0,85 ; \mathrm{p} \leq 0,01)$. A hiperplasia de células granulocíticas observada no intestino de cáes infectados por $L$. infantum sugere que essas células podem estar envolvidas na resposta imune mediada por células para a eliminação do parasita.

Palavras-chave: Leishmaniose visceral canina, trato intestinal, granulócitos.

\footnotetext{
*Corresponding author: Wilma Aparecida Starke-Buzetti. Departamento de Biologia e Ciência Animal, Faculdade de Engenharia de Ilha Solteira - FEIS, Universidade Estadual Paulista - UNESP, Av. Brasil, 56, CEP 15385-000, Ilha Solteira, SP, Brasil. e-mail: wilma.buzetti@unesp.br
} 


\section{Introduction}

Canine visceral leishmaniasis (CVL) is a parasitic disease caused by protozoa of the genus Leishmania (ROSS, 1903). The species Leishmania infantum (syn. L. chagasi) is the causative agent of visceral leishmaniasis in the New World, with endemic regions extending from southern USA to northern Argentina, including Brazil (KUHLS et al., 2011).

The main route of transmission to humans and animals is through the bite of the sandfly species Lutzomyia (L.) longipalpis (Diptera: Psychodidae: Phlebotominae) (PORROZZI et al., 2006). After the parasite is inoculated into the host skin, it multiplies inside the cytoplasm of macrophages.

The infection affects the liver, spleen, lymph nodes, bone marrow and other organs in the gastrointestinal, central nervous, genital, and urinary systems (CHIAPELLA, 1986; BLAVIER et al., 2001; DINIZ et al., 2005; GIUNCHETTI et al., 2008; MOREIRA et al., 2016). Classic canine leishmaniasis appears clinically as a chronic wasting disease, with anemia, cutaneous lesions, generalized lymphadenopathy, glomerulonephritis, epistaxis, chronic colitis, hemorrhagic diarrhea, arthritis, ophthalmic lesions, keratoconjunctivitis or uveitis (FERRER et al., 1991; CIARAMELLA et al., 1997; BLAVIER et al., 2001; TAFURI et al., 2001).

An inflammatory reaction in the gastrointestinal tract associated with the presence of intramacrophagic Leishmania amastigotes has been reported in experimentally infected dogs (CHIAPELLA, 1986; KEENAN et al., 1984) and in naturally infected dogs (FERRER et al., 1991; PINTO et al., 2011; TOPLU \& AYDOGAN, 2011; SILVA et al., 2016). In experimental studies using hamsters as models for Leishmania infection, González et al. (1986) described the pathological alterations associated with inflammatory infiltration of lymphocytes, plasma cells and macrophages in the intestinal lamina propria and colon submucosa of infected animals. Although uncommon, occurrences of erosive and ulcerative colitis and hemorrhagic diarrhea have been described in dogs in association with severe clinical signs of the disease (GONZÁLEZ et al., 1990; FERRER et al., 1991). However, the prevalence of Leishmania parasitism detected in the colonic mucosa through colonoscopy, but without overt colitis, was surprisingly high in dogs with symptomatic leishmaniasis (PLEVRAKI et al., 2007).

More recently, Silva et al. (2002), Pinto et al. (2011), Figueiredo et al. (2014) and Silva et al. (2016) investigated symptomatic dogs naturally infected with L. infantum. The authors observed high parasite burden throughout the intestinal mucosa (predominantly in the colon) without marked pathological alterations, suggesting that Leishmania may cause intestinal immunological tolerance.

After the onset of infection, the parasites are susceptible to the action of neutrophils, but with the rapid entry of amastigotes into macrophages, they escape the microbicidal mechanisms of neutrophils (MACHADO et al., 2004) and begin to proliferate inside the mononuclear phagocytic system. The function of neutrophils has been evaluated both in early and advanced stages of leishmaniasis in an attempt to understand the susceptibility of animals to the disease. Neutrophils are the first line of host defense (CIARLINI et al., 2010; GÓMEZ-OCHOA et al., 2010). Other granulocytic cells such as mast cells and eosinophils are also important in the control of Leishmania spp. infection. Pearson \& Steigbigel (1981) showed that eosinophils have microbicidal activity against Leishmania spp. and Wershil et al. (1994) reported that mast cells are involved in the regulation of immunity against several species of Leishmania.

The activation of eosinophils in a microenvironment containing interferon-gamma (IFN- $\gamma$ ) may stimulate the production of various inflammatory mediators. In addition, the expression of membrane receptors such as toll-like 4, 7, and 8 on the cell surface of eosinophils activated by IFN- $\gamma$ could represent an important mode of interaction between eosinophils and Leishmania spp., promoting the elimination of the parasite by these cells (NAGASE et al., 2003).

According to Cardoso et al. (2017) the mast cells may be involved in remodeling tissue of dogs naturally infected by $L$. infantum because of the low parasite load associated with higher numbers of mast cells observed in ear skin of infected dogs than in control group (healthy dogs).

Mast cells in the skin of mice infected with Leishmania major are required for the recruitment of macrophages during the formation of cutaneous granuloma, a typical characteristic of inflammatory response induced by the parasite. Skin protection by mast cells depends on the pathological effects of parasitic infection and is determined by its influence on the innate and adaptive immune responses (VON STEBUT et al., 2003). Mast cells are important in host defense against pathogens (MAURER et al., 2006) and can regulate $\mathrm{T}$-cell immune responses both directly (through expression of MHC Class II molecules and production of chemotactic factors, Th1 or Th2-related cytokines) and indirectly (through regulation of dendritic cell migration, maturation and function) (GALLI et al., 2005; GALLI et al., 2008).

The population of granulocytic cells in the intestinal mucosa of dogs naturally infected with $L$. infantum with or without the parasite in the intestinal tract has not yet been characterized. Thus, the goal of this study was to quantify the different granulocytic cell types in L. infantum-infected dogs with and without intestinal infection and correlate the frequency of the cell types to each other and to parasite burden. The characterization of granulocytic cell populations may help understanding their role against this protozoan infection in the intestinal tract of dogs.

\section{Material and Methods}

\section{Animals, study location, and ethical aspects}

Twenty dogs of various breeds were included in the study: 17 dogs were symptomatic for CVL and three were uninfected controls; eight dogs (40\%) were sexually intact males and 12 (60\%) were intact females, with ages ranging from one to seven years (mean age: 3.2 years). Dogs with CVL were kindly donated by the Zoonosis Control Center (ZCC) from Ilha Solteira $\left(51^{\circ} 06^{\prime} 35^{\prime \prime} \mathrm{W}\right.$ and $20^{\circ} 38^{\prime} 44^{\prime \prime} \mathrm{S}$ ) and by a Veterinary Clinic in the municipality of Andradina ( $20^{\circ} 53^{\prime} 38^{\prime \prime} \mathrm{S}$ and $\left.51^{\circ} 23^{\prime} 1^{\prime \prime} \mathrm{W}\right)$, state of São Paulo, Brazil. 
The diagnosis was confirmed in our laboratory using ELISA test, an indirect immunofluorescence antibody test (IFAT), both according to Oliveira et al. (2008), and the polymerase chain reaction (PCR) as described by Cortes et al. (2004).

The dogs were assigned to one of three groups: group $1(\mathrm{G} 1, \mathrm{n}=8)$, dogs with CVL with L. infantum amastigotes in the intestine; group $2(\mathrm{G} 2, \mathrm{n}=9)$, dogs with CVL without amastigotes in the intestine; and group 3 (G3, n=3), uninfected dogs (control group). Amastigotes detection was performed using a parasitological direct examination in microscope, an immunohistochemistry test and PCR. The dogs from G1 group were CVL polysymptomatic dogs and the main clinical signs observed were onychogryphosis, lymphadenomegaly, weight lost, skin lesions, apathy, opaque bristles and/or alopecia, conjunctivitis, anemia and diarrhea.

Dogs co-infected with L. infantum and other intestinal parasitic agents were excluded from this work.

The study was approved by the Ethics Committee for Animal Use (CEUA) of São Paulo State University, Ilha Solteira Campus (FEIS-UNESP), School of Natural Sciences and Engineering, Ilha Solteira, Department of Biology and Animal Science, under protocol no. 06/2014-CEUA.

\section{Control group (uninfected dogs)}

Uninfected dogs (G3) were euthanized after injuries they sustained in traffic accidents. Before death, the animals were attended at a veterinary clinic where feces, urine, lymph node, bone marrow, and blood samples were collected for clinical, parasitological, biochemical, serological, and molecular exams. The results of all exams were negative for CVL and the dogs had no clinical signs of leishmaniasis. After euthanasia, samples of intestinal tissues were collected.

The hepatic and renal function of control dogs was analyzed and all results were normal.

\section{Euthanasia and necropsy procedures for tissue sample collection}

Euthanasia and necropsy procedures of Leishmania infected dogs were performed in the ZCC from Ilha Solteira, SP, following procedure no. 1000/2012 from the Brazilian Federal Council of Veterinary Medicine (CFMV) as recommended by the Decree no. 51,838 of Brazilian Federal law published on March 14, 1963.

Following euthanasia, the abdominal cavities of dogs were opened for examination and organs and tissues were removed. First, the small intestine (duodenum, jejunum, and ileum) was separated from the large intestine (ascending colon) and 0.5 - to $1-\mathrm{cm}$ long fragments were collected, washed with phosphate buffered saline (PBS, $\mathrm{pH}=7.4$ ), and fixed in 10\% buffered formalin in $0.01 \mathrm{M} \mathrm{PBS}$ for $24 \mathrm{~h}$ for histopathological and immunohistochemical procedures.

The necropsy and tissue collection of control dogs followed the same procedures as described above.

Feces samples and intestinal contents of the small and large intestines were collected after death, identified, packed in ice, and sent to the laboratory for parasitological analysis. The results showed that the dogs did not have any gastrointestinal parasites, with the exception of $L$. infantum amastigotes in the intestinal tissues of dogs from the G1 group.

\section{Histological procedures}

The intestinal tissues were fixed, embedded in paraffin, cut into $5-\mu \mathrm{m}$ thick sections, and stained with hematoxylin and eosin (HE) for histological examination. HE-stained neutrophils were identified and counted. Histochemistry staining for mast cells and eosinophils were performed according to the technique described by Duffy et al. (1993) and immunohistochemistry was performed according to the procedures described by Tafuri et al. (2004) and adapted by Queiroz et al. $(2010,2011)$. After rinsing in distilled water, tissues were counterstained with Mayer hematoxylin, dehydrated, and the slides were mounted with coverslips using Canada balsam. As reaction control, one slide of each tissue was not incubated with the primary antibody. In addition, tissues from dogs in the control group (uninfected dogs) were used as negative control and tissues from $L$. infantum-infected dogs were used as the positive control. Two slides of each tissue from groups G1, G2, and G3 were analyzed.

\section{Quantitative analysis of granulocytic cells}

The number of neutrophils, eosinophils, and mast cells per crypt-villus unit (CVU) was determined in the intestinal mucosa of the small intestine (duodenum, jejunum, and ileum) and large intestine (ascending colon). For each intestinal segment, 15 CVUs were evaluated per animal. In the submucosa (SB) and muscle layer (ML), each cell type was counted in $150.5-\mathrm{mm}^{2}$ areas corresponding to 15 CVUs according to Neves et al. (2003).

Cells were identified and counted in two sections per animal tissue of each group in a light microscopy under an objective lens of $40 \times$ for mast cells and $100 \times$ for eosinophils and neutrophils. Counting was carried out in a blind fashion, without previous knowledge of the infection status of the sample.

\section{Statistical analysis}

The homoscedasticity and normality of residues were checked using the Shapiro-Wilks test, and the homogeneity of variances was tested using the Levene's test. Mean neutrophil, eosinophil, and mast cell counts in CVU, SB, and ML from the three experimental groups (G1, G2, and G3) were evaluated by analysis of variance (ANOVA) using the F test, and group means were compared by the Tukey's test using the "agricolae" data package.

The correlation between cell numbers and parasite burden was determined using the Pearson's linear correlation coefficient. For all tests, 95\% confidence intervals were calculated and $\mathrm{p}$ values $\leq 0.05$ were considered significant. All analyses were performed using R statistical software version 3.1.1 (R CORE TEAM, 2018).

\section{Results}

Granulocytic cells (mast cells, neutrophils, and eosinophils) were quantified in the intestinal wall, including the mucosa, represented by crypt-villus units (CVUs), submucosa (SB), and muscle layer (ML), along three segments of the small intestine (duodenum, jejunum and ileum) and in the large intestine (colon). Granulocytic cell counts in the small and large intestines were significantly higher 
in G2 dogs followed by G1 dogs ( $\mathrm{p} \leq 0.05)$ than in control dogs (G3). Cell numbers were higher in CVUs (mucosa) than in the SB and ML layers. The numbers of neutrophils and eosinophils were significantly higher in the small intestine than in the large intestine in both groups (G1 and G2), but mast cell counts were similar in the small and large intestines.

In the mucosa (CVU), mast cell (stained in blue) counts were higher than neutrophil and eosinophil counts, both in the small and large intestines. Mast cells were abundantly distributed in the lamina propria of the villi and crypts (Figure $1 \mathrm{~A}$ and $1 \mathrm{~B}$ ), and in the SB and ML, where they were seen associated with the myenteric nervous plexus (Figure 1C). Eosinophils, identified by red granules, were detected in villi and at the base of crypts (Figure 1D and E). Neutrophils, identified by a polymorphic nucleus, were clearly observed in the villi and inside the small blood vessels (Figure 1F). Granulocytic cell counts (mast cells, neutrophils, and eosinophils)
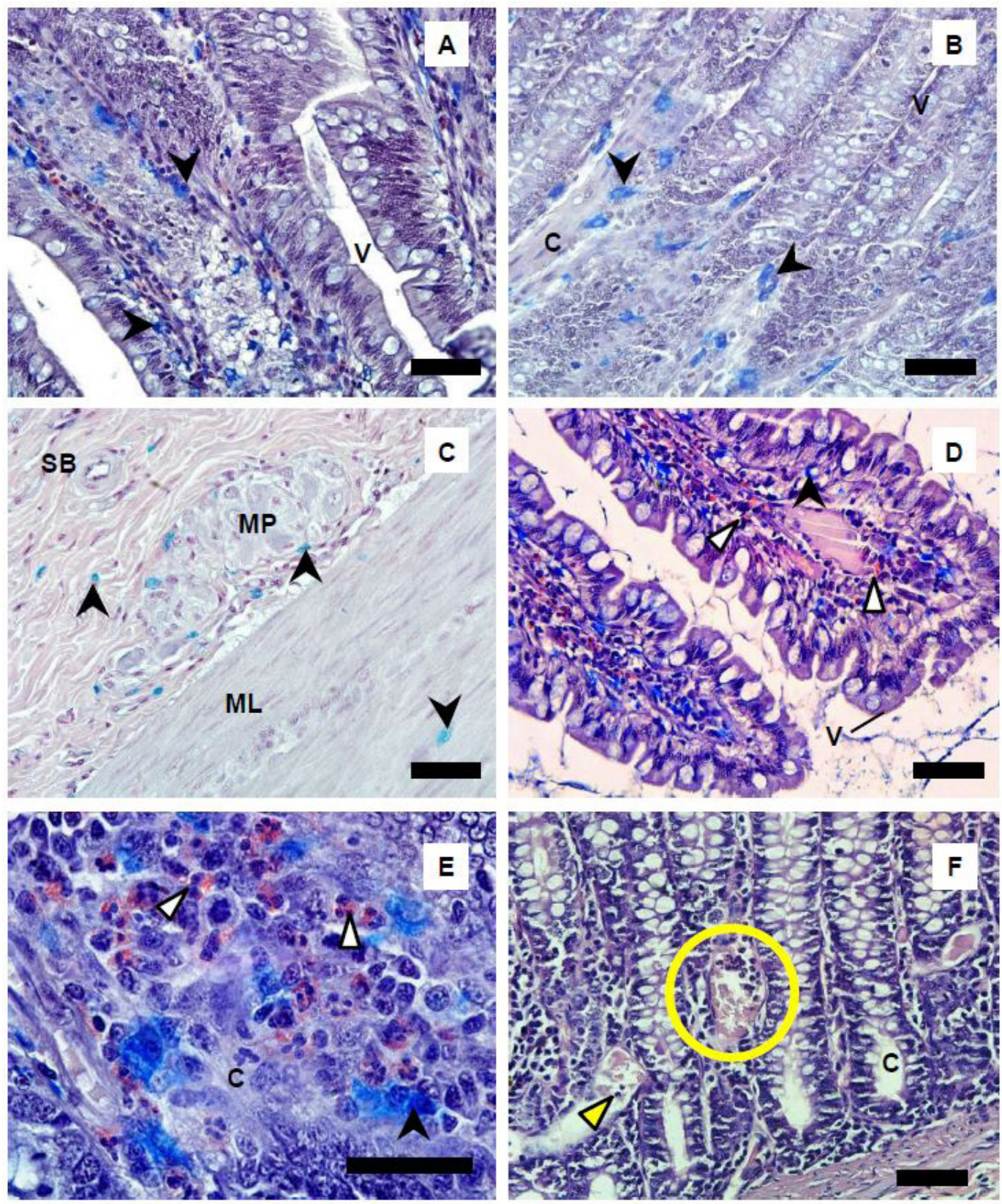

Figure 1. Histological sections of the intestine of dogs infected with L. infantum. A, B, and $\mathrm{E}=\operatorname{dogs}$ without L. infantum amastigotes in the intestine (G2 group); C, D, and F = dogs with intestinal amastigotes (G1 group). A (duodenum): mast cells (black arrows) inside the lamina propria of villus (40× magnification). B (colon): mast cells (black arrows) at the bottom of a crypt (40×). C (jejunum): presence of mast cells in the submucosa associated with myenteric nervous plexus and muscle layers (40x). D (duodenum): presence of eosinophils at the tip of villi (white arrows; $40 \times$ ). E (duodenum): eosinophils at the base of a crypt (tip of white arrows; 100×). F (colon): neutrophils (yellow arrowhead and inside the circle) around a crypt $(40 \times) . V=$ villus; $C=$ crypt; $\mathrm{SB}=$ submucosa; $\mathrm{MP}=$ myenteric nervous plexus; $\mathrm{ML}=$ muscle layer. Staining: Astra blue and Direct red 75. Bars $=50 \mu \mathrm{m}$. Ilha Solteira, SP, Brazil, 2017. 
were significantly higher in the CVUs of G2 dogs, followed by G1 and G3 dogs ( $\mathrm{p} \leq$ 0.05; Figures 2A, 3A, and 4A).

In the submucosa, mast cell and eosinophil counts in the duodenum, jejunum, and colon were significantly higher in G1 and G2 than G3. However, in the ileum, no significant differences were detected in mast cell and eosinophil numbers between the
G1, G2, and G3 groups (Figure 3B and 4B). Neutrophil counts were significantly higher in G2 than G1 and G3 in the jejunum, ileum, and colon, but no significant difference was detected across groups in the duodenum (Figure 2B).

In the ML, neutrophil and eosinophil numbers were similar across groups $(\mathrm{p} \geq 0.05)$ in all intestinal segments (Figure $2 \mathrm{C}$ and
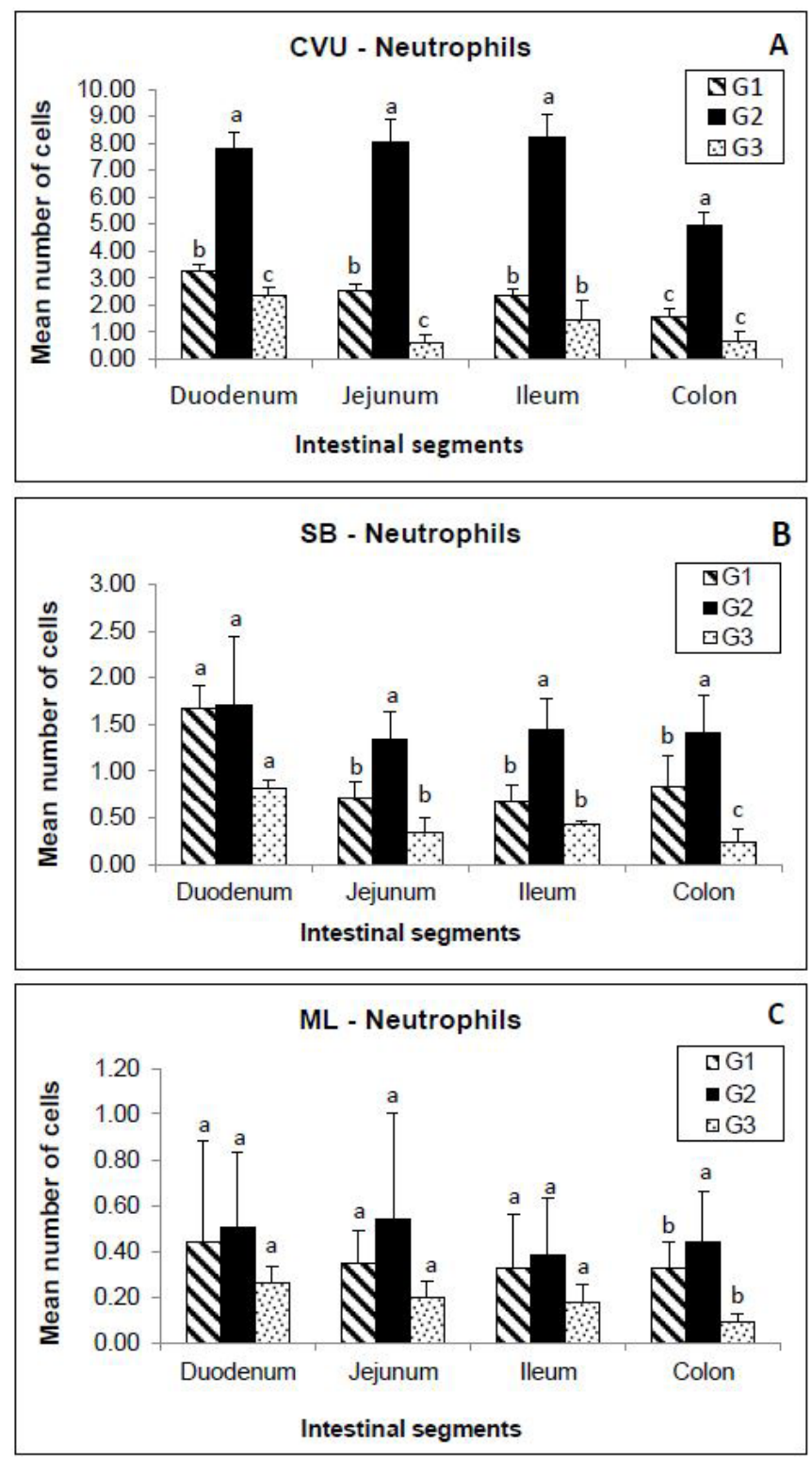

Figure 2. Mean number of neutrophils across crypt-villus units (CVU), submucosa (SB), and muscle layer (ML) of the duodenum, jejunum, ileum, and colon of dogs with visceral leishmaniasis and infected with $L$. infantum amastigotes in the intestine $(\mathrm{G} 1=8)$, dogs with leishmaniasis but no intestinal amastigotes $(\mathrm{G} 2, \mathrm{n}=9)$, and uninfected dogs (control group, G3 = 3). The standard deviation (SD) of the mean is represented by the vertical lines above the bars. Different lowercase letters (a / b / c) indicate statistical difference between (G1, G2, and G3) within each intestinal segment at 5\% probability ( $\mathrm{p} \leq 0.05)$. Analysis of variance (ANOVA), and Tukey's test. Program R version 3.1.1 (R CORE TEAM, 2018). Ilha Solteira, SP, Brazil, 2018.
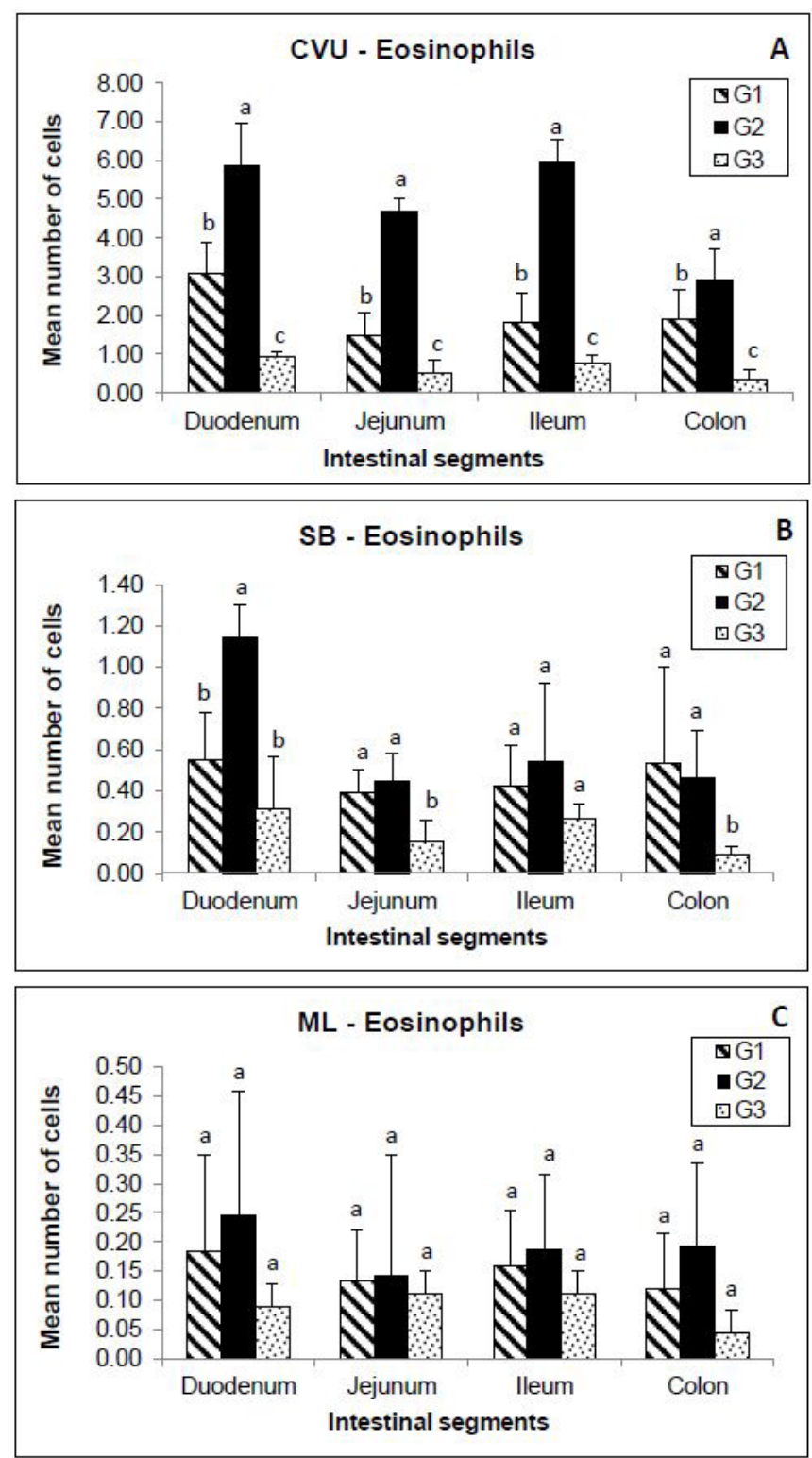

Figure 3. Mean number of eosinophils across crypt-villus units (CVU), submucosa (SB), and muscle layer (ML) of the duodenum, jejunum, ileum, and colon of dogs with visceral leishmaniasis and infected with $L$. infantum amastigotes in the intestine $(\mathrm{G} 1=8)$, dogs with leishmaniasis but no intestinal amastigotes $(\mathrm{G} 2, \mathrm{n}=9)$, and uninfected dogs (control group, G3 = 3). The standard deviation (SD) of the mean is represented by the vertical lines above the bars. Different lowercase letters (a / b / c) indicate statistical difference between (G1, G2, and G3) within each intestinal segment at 5\% probability ( $\mathrm{p} \leq 0.05)$. Analysis of variance (ANOVA), and Tukey's test. Program R version 3.1.1 (R CORE TEAM, 2018). Ilha Solteira, SP, Brazil, 2018. 
Figure 3C). However, mast cell counts were higher in the small intestine (duodenum, jejunum, and ileum) and were significantly different across groups $(\mathrm{G} 2>\mathrm{G} 1>\mathrm{G} 3, \mathrm{p} \leq 0.05)$. In the large intestine, mast cell counts were significantly higher in G1 and G2 than G3 (Figure 4C).

In $\mathrm{G} 1$ dogs, there was a low inverse correlation between parasite burden of the small intestine and granulocyte counts
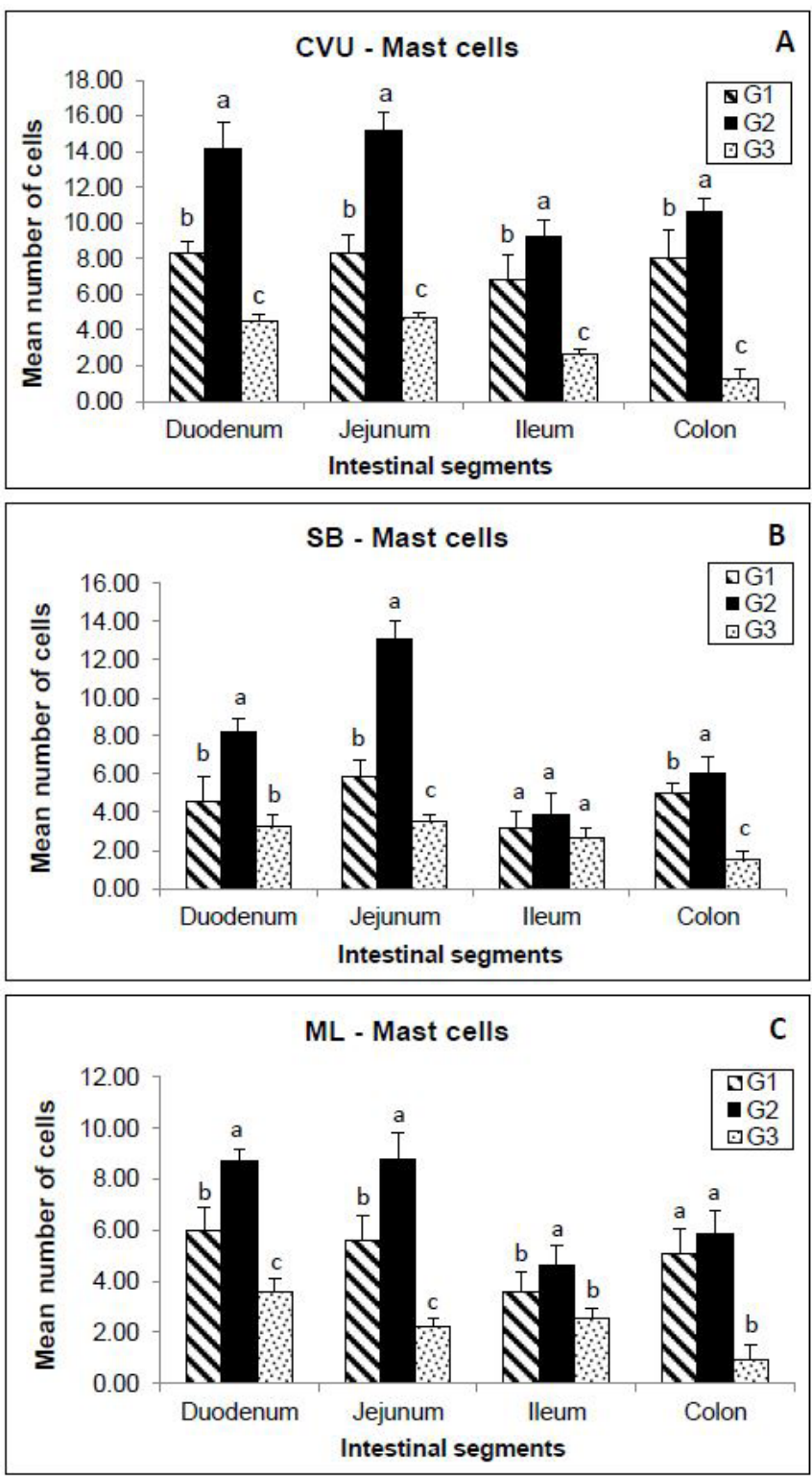

Figure 4. Mean number of mast cells across crypt-villus units (CVU), submucosa (SB), and muscle layer (ML) of the duodenum, jejunum, ileum, and colon of dogs with visceral leishmaniasis and infected with $L$. infantum amastigotes in the intestine $(\mathrm{G} 1=8)$, dogs with leishmaniasis, but no intestinal amastigotes $(\mathrm{G} 2, \mathrm{n}=9)$, and uninfected dogs (control group, G3 = 3). The standard deviation (SD) of the mean is represented by the vertical lines above the bars. Different lowercase letters $(\mathrm{a} / \mathrm{b} / \mathrm{c}$ ) indicate statistical difference between (G1, G2, and G3) within each intestinal segment at 5\% probability ( $\mathrm{p} \leq 0.05)$. Analysis of variance (ANOVA), and Tukey's test. Program R version 3.1.1 (R CORE TEAM, 2018). Ilha Solteira, SP, Brazil, 2018 $(\mathrm{r}=-0.1, \mathrm{p} \leq 0.01)$ whereas in G2 dogs, there was a positive correlation between mast cell and eosinophil numbers $(r=0.85$, $\mathrm{p} \leq 0.01)$.

\section{Discussion}

In this study, dogs in the $\mathrm{G} 1$ and $\mathrm{G} 2$ groups were symptomatic and positive for CVL, but only G1 dogs $(40.0 \%, 8 / 20)$ had L. infantum amastigotes in the intestinal wall. Amastigotes of L. infantum were identified in the tissues by immunostaining and were observed outside and inside of macrophages in villi, crypts, submucosa, and circular or longitudinal smooth muscle layers of the small and large intestines, but particularly in the large intestine. Similar findings were reported by Silva et al. (2002), Plevraki et al. (2007), Pinto et al. (2011), Figueiredo et al. (2014) and Silva et al. (2016), who described the intestinal mucosal alterations associated with mononuclear cellular infiltration, especially of macrophages, lymphocytes, and plasma cells. The clinical alterations of the gastrointestinal tract of the dogs of this study can be better understood in the work of Silva et al. (2016)

In this study, we investigated the role of granulocytic cells (neutrophils, eosinophils, and mast cells) on intestinal leishmaniasis in dogs. We observed that cell numbers were increased in the intestinal mucosa, specifically in crypt-villus units and submucosa from dogs infected with L. infantum (G1 and G2 groups). This increase was significantly higher in G1 and G2 dogs when both groups were compared with the control group (G3). Mast cells were the most abundant cell type, followed by neutrophils and eosinophils.

Granulocytic cell numbers, especially those of neutrophils and eosinophils from G1 dogs, were significantly higher in the small intestine than in the large intestine, and inversely correlated with parasite burden of the small intestine, indicating that when granulocytic cell counts increased, parasite burden was reduced. Similarly, hyperplasia of granulocytic cells was not observed in the submucosa of the ileum of G1 dogs, in contrast to the high parasite burden found in that intestinal segment. According to Simecka (1998), antigenic stimuli have been identified at particular sites in the intestinal mucosa (e.g., the first portion of the small intestine). However, the response to these stimuli, including the secretion of inflammatory mediators and cellular sensitivity, can extend to other intestinal portions, possibly through blood and lymphatic vessels in the intestinal mucosa, Peyer's patches, and/or mesenteric lymph nodes. Thus, despite the absence of intestinal amastigotes in dogs from the G2 group, it is possible that antigenic stimuli in other organs such as the liver, spleen, lymph nodes, and/or bone marrow could have extended their protective effect to the intestinal mucosa of those dogs, which may explain the hyperplasia of polymorphonuclear cells (PMNs) and mast cells in the intestine and indicate that this acute inflammatory process prevented the intestinal infection by the parasite.

At the beginning of infection, Leishmania spp. may be able to inhibit the neutrophil oxidative metabolism to prolong the survival of cells and parasites inside the cells. This causes the neutrophils to act as a 'Trojan horse', enabling the expansion and replication of the parasite in neutrophils and in the host (LAUFS et al., 
2002; LASKAY et al., 2003). In contrast, increased production of superoxide molecules has been observed in neutrophils of dogs with established CVL (CIARLINI et al., 2010; GÓMEZ-OCHOA et al., 2010), which could contribute significantly to the cellular oxidative stress able to kill the parasites. In the current study, we observed neutrophil hyperplasia in dogs from the G1 and G2 groups, mostly in CVUs. However, we did not evaluate the oxidative metabolism or the production of superoxide by these cells, which could have indicated their participation in the establishment of infection in the intestinal tract of animals from the G1 group and played a role in preventing infection in the intestinal tissues of dogs from the G2 group, even though neutrophil hyperplasia could also indicate an acute inflammatory process. Regardless of the fact that $L$. infantum may regulate or inhibit neutrophil action, neutrophils still play an important role against other infections that may develop in dogs with CVL, mainly secondary infections caused by immunosuppressive pathways mediated by the parasite. Because of their intense phagocytic role, neutrophils receive stimuli from toll-like receptors to recognize pathogen-associated molecular patterns (PAMPs) to eliminate intracellular parasites (MESQUITA, 2008).

Eosinophil hyperplasia was also significant in intestinal tissues of L. infantum-infected dogs (G1 and G2 groups). It is believed that the activation of eosinophils in a microenvironment containing IFN- $\gamma$ would lead to the stimulation of various inflammatory mediators. In addition, the expression of receptors such as toll-like receptor 4,7 , and 8 on the cell surface of IFN- $\gamma$-activated eosinophils could represent an important route of eosinophil-Leishmania spp. interaction that would promote the elimination of the parasite by these cells (NAGASE et al., 2003). Thus, the increase in eosinophil counts in the intestinal tract of dogs with L. infantum amastigotes (G1 group) could represent an additional leishmanicidal mechanism. However, more studies are needed to determine the role of eosinophils in combating $L$. infantum infection.

Mast cell numbers were also significantly higher in the intestinal tissues of infected dogs (G1 and G2) compared to controls. According to Levy \& Frondoza (1983), mast cells are associated with parasitic infections, but can also mediate protection against bacterial pathogens (HENZ et al., 2001), and are important sentinels of innate immunity cells for host defense against intracellular pathogens (MAURER et al., 2006). In the current study, mast cells were detected in villi and crypts, in the submucosa, and associated with the myenteric nervous plexus of the smooth muscle layers of the small intestine of $L$. infantum-infected dogs with and without $L$. infantum amastigotes, suggesting that intestinal mast cell hyperplasia is linked to host defense activities (MAURER et al., 2006).

According to Maurer et al. (2006), mast cells are one of the first cells to arrive at the site of infection, and by releasing inflammatory mediators, can recruit pro-inflammatory cellular elements such as neutrophils, macrophages, and dendritic cells in an attempt to cause an unfavorable environment for parasite survival. In our study, granulomatous processes were noted in G1 samples, usually in the mucosa and submucosa with presence of macrophages and other mononuclear cells. Thus, the mast cells observed in the intestines of G1 dogs may be involved in macrophage recruitment and granuloma formation. The protection triggered by mast cells depends on the pathological effects of parasitic infection that mediate the innate immune response (VON STEBUT et al., 2003).

There was a significant reduction in the number of PMN cells (neutrophils and eosinophils) and mast cells in dogs from G1 in relation to G2, but cell counts in G1 dogs were significantly higher than in uninfected controls (G3). This result suggests that parasites in the intestinal tract of G1 dogs are adapted to the host immune system leading to immune regulation and increasing the parasite survival, which may explain the reduction in cell counts from G2 to G1. Consistently, Pinto et al. (2011) suggested that L. infantum amastigotes may benefit from the intestinal immune regulatory response due to immune tolerance. In addition, the presence of parasites in G1 dogs may explain the difference in cell numbers when compared with healthy negative controls.

Many factors have been implicated in immunosuppression in VL: soluble IL-2 receptor (BARRAL-NETTO et al., 1991), defective antigen-presenting cell function (REINER et al., 1987; RODRIGUES-JÚNIOR et al., 1992), TGF- $\beta$ (RODRIGUES et al., 1998) inhibition of macrophage activity (KEHRL et al., 1986), and reduced production of nitric oxide (NO) (MELBY et al., 2001). Possibly some of these factors have contributed to an immune regulation in the intestine of G1 dogs, increasing the survival of the parasite in this organ; however, none of these mechanisms was evaluated in our study, and further research is needed to determine the role of immunosuppression in intestinal wall of dogs with L. infantum.

We found a significant positive correlation between mast cell and eosinophil numbers in the small and large intestine of G2 dogs. In contrast, in G1 and in the uninfected control group (G3), there was no significant correlation between mast cells and eosinophils. Meeusen \& Balic (2000) reported that mast cells, natural killer (NK) cells, and intraepithelial lymphocytes (IELs) can secrete IL-5, which induces the proliferation and migration of eosinophils from the bone marrow to the site of infection. Thus, the positive correlation between mast cells and eosinophils observed in the intestinal wall of G2 dogs suggests a possible synergy between these two cell types, with mast cells recruiting eosinophils during infection. Conversely, in uninfected dogs (G3), the eosinophil-recruiting activity of mast cells may be suppressed, resulting in a diminished eosinophil population.

\section{Conclusions}

Granulocytic cell hyperplasia (neutrophils, eosinophils, and mast cells) was detected in the intestinal wall of $L$. infantum -infected dogs with (G1 group) and without (G2 group) intestinal amastigotes in small and large intestine. In addition, cell counts were significantly higher in G2 than G1, and there was a low inverse correlation between parasite burden and granulocyte counts in the small intestine of G1 dogs, suggesting that these cells may be involved in cell-mediated immune response and parasite elimination.

The positive correlation between mast cells and eosinophils observed in the intestinal wall of G2 dogs provides evidence of synergy between these cells, whereby mast cells recruit eosinophils to the intestine before the establishment of the parasite infection. 


\section{Acknowledgements}

The authors thank São Paulo Research Foundation (FAPESP, no2013/13875-5) and Coordination for Improvement at Personnel Superior Education Level (CAPES) for financial support, and the Zoonotic Disease Control Center (ZCC) of Ilha Solteira, SP for donating the biological material from the dogs.

\section{References}

Barral-Netto M, Barral A, Santos SB, Carvalho EM, Badaro R, Rocha $\mathrm{H}$, et al. Soluble IL-2 receptor as an agent of serum mediated suppression in human visceral leishmaniasis. J Immunol 1991; 147(1): 281-284. PMid:1904902.

Blavier A, Keroack S, Denerolle P, Goy-Thollot I, Chabanne L, Cadoré JL, et al. Atypical Forms of Canine Leishmaniosis. Vet J 2001; 162(2): 108-120. http://dx.doi.org/10.1053/tvjl.2000.0556. PMid:11531395.

Cardoso JMO, Ker HG, Aguiar-Soares RDO, Moreira ND, Mathias FAS, Reis LES, et al. Association between mast cells, tissue remodelation and parasite burden in the skin of dogs with visceral leishmaniasis. Vet Parasitol 2017; 243: 260-266. http://dx.doi.org/10.1016/j.vetpar.2017.05.028. PMid:28807304.

Chiapella A. Diagnosis and management of chronic colitis in the dogs and cat. In: Kirk R. Current Veterinary Therapy: IX Small Animal Practice. Philadelphia: W.B. Saunders; 1986. p. 896-993.

Ciaramella P, Oliva G, Luna RD, Gradoni L, Ambrosio R, Cortese $\mathrm{L}$, et al. A retrospective clinical study of canine leishmaniasis in 150 dogs naturally infected by Leishmania infantum. Vet Rec 1997; 141(21): 539-543. http://dx.doi.org/10.1136/vr.141.21.539. PMid:9413121.

Ciarlini PC, Valadares TC, Ikeda-Garcia FA, Marcondes M, Lima VMF. Leucograma e metabolismo oxidativo dos neutrófilos de cães com leishmaniose visceral antes e após o tratamento com antimoniato de meglumina e alopurinol. Cienc Anim Bras 2010; 11(2): 369-375. http:// dx.doi.org/10.5216/cab.v11i2.2149.

Cortes S, Rolão N, Ramada J, Campino L. PCR as a rapid and sensitive tool in the diagnosis of human and canine leishmaniasis using Leishmania donovani s.l. - specific kinetoplastid primers. Trans R Soc Trop Med Hyg 2004; 98(1): 12-17. http://dx.doi.org/10.1016/S0035-9203(03)000026. PMid:14702834.

Diniz SA, Melo MS, Borges AM, Bueno R, Reis BP, Tafuri WL, et al. Genital Lesions Associated with Visceral Leishmaniasis and Shedding of Leishmania sp. in the Semen of Naturally Infected Dogs. Vet Pathol 2005; 42(5): 650-658. http://dx.doi.org/10.1354/vp.42-5-650. PMid:16145211.

Duffy JP, Smith PJ, Crocker J, Matthews HR. Combined Staining Method for the Demonstration of Tissue Eosinophils and Mast Cells.J Histotechnol 1993; 16(2): 143-144. http://dx.doi.org/10.1179/his.1993.16.2.143.

Ferrer L, Juanola B, Ramos JA, Ramis A. Chronic colitis due to Leishmania infection in two dogs. Vet Pathol 1991; 28(4): 342-343. http://dx.doi. org/10.1177/030098589102800414. PMid:1949514.

Figueiredo MM, Deoti B, Amorim IF, Pinto AJW, Moraes A, Carvalho $\mathrm{CS}$, et al. Expression of regulatory T cells in jejunum, colon, and cervical and mesenteric lymph nodes of dogs naturally infected with Leishmania infantum. Infect Immun 2014; 82(9): 3704-3712. http://dx.doi.org/10.1128/ IAI.01862-14. PMid:24935975.
Galli SJ, Nakae S, Tsai M. Mast cells in the development of adaptive immune responses. Nat Immunol 2005; 6(2): 135-142. http://dx.doi. org/10.1038/ni1158. PMid:15662442.

Galli SJ, Nakae S, Tsai M. Histopathology, parasite density and cell phenotypes of the popliteal lymph node in canine visceral leishmaniasis. Vet Immunol Immunopathol 2008; 121(1-2): 23-33. http://dx.doi. org/10.1016/j.vetimm.2007.07.009. PMid:17723246.

Giunchetti RC, Martins-Filho OA, Carneiro CM, Mayrink W, Marques MJ, Tafuri WL, et al. Histopathology, parasite density and cell phenotypes of the popliteal lymph node in canine visceral leishmaniasis. Vet Immunol Immunopathol 2008; 121(1-2): 23-33. http://dx.doi.org/10.1016/j. vetimm.2007.07.009. PMid:17723246.

Gómez-Ochoa P, Lara A, Couto G, Marcen JM, Peris A, Gascón $\mathrm{M}$, et al. The nitroblue tetrazolium reduction test in canine leishmaniasis. Vet Parasitol 2010; 172(1-2): 135-138. http://dx.doi.org/10.1016/j. vetpar.2010.04.024. PMid:20483539.

González JL, Fermin ML, Garcia P, Rollan E, Castaño M. Erosive colitis in experimental canine Leishmaniasis. Zentralbl Veterinarmed B 1990; 37(5): 377-382. PMid:2396485.

González JL, Insa F, Novoa C, Pizarro M. Intestinal amyloidosis in hamsters with visceral leishmaniasis. Br J Exp Pathol 1986; 67(3): 353360. PMid:3718842.

Henz BM, Maurer M, Lippert U, Worm M, Babina M. Mast cells as initiators of immunity and host defense. Exp Dermatol 2001; 10(1): 1-10. http://dx.doi.org/10.1034/j.1600-0625.2001.100101.x. PMid:11168574.

Keenan CM, Hendricks LD, Lightner L, Webster HK, Johnson AJ. Visceral leishmaniasis in the German Shepherd dog. I. Infection, clinical disease, and clinical pathology. Vet Pathol 1984; 21(1): 74-79. http:// dx.doi.org/10.1177/030098588402100113. PMid:6710816.

Kehrl JH, Wakefield LM, Roberts AB, Jakowlew S, Alvarez-Mon M, Derynck RIK, et al. Production of transforming growth factor beta by human $\mathrm{T}$ lymphocytes and its potential role in the regulation of T cell growth. J Exp Med 1986; 163(5): 1037-1050. http://dx.doi.org/10.1084/ jem.163.5.1037. PMid:2871125.

Kuhls K, Alam MZ, Cupolillo E, Ferreira GEM, Mauricio IL, Oddone $\mathrm{R}$, et al. Comparative microsatellite typing of new world Leishmania infantum reveals low heterogeneity among populations and its recent old world origin. PLoS Negl Trop Dis 2011; 5(6): e1155. http://dx.doi. org/10.1371/journal.pntd.0001155. PMid:21666787.

Laskay T, Van Zandbergen G, Solbach W. Neutrophil granulocytes Trojan horses for Leishmania major and other intracellular microbes? Trends Microbiol 2003; 11(5): 210-214. http://dx.doi.org/10.1016/ S0966-842X(03)00075-1. PMid:12781523.

Laufs H, Müller K, Fleischer J, Reiling N, Jahnke N, Jensenius JC, et al. Intracellular Survival of Leishmania major in neutrophil granulocytes after uptake in the absence of heat-labile serum factors. Infect Immun 2002; 70(2): 826-835. http://dx.doi.org/10.1128/IAI.70.2.826-835.2002. PMid:11796617.

Levy DA, Frondoza C. Immunity to intestinal parasites: role of mast cells and goblet cells. Fed Proc 1983; 42(6): 1750-1755. PMid:6832397.

Machado PRL, Araújo MIAS, Carvalho L, Carvalho EM. Mecanismos de resposta imune às infecçóes. An Bras Dermatol 2004; 79(6): 647-664. http://dx.doi.org/10.1590/S0365-05962004000600002.

Maurer M, Lopez Kostka S, Siebenhaar F, Moelle K, Metz M, Knop J, et al. Skin mast cells control T cell-dependent host defense in Leishmania 
major infections. FASEB J 2006; 20(14): 2460-2467. http://dx.doi. org/10.1096/fj.06-5860com. PMid:17142795.

Meeusen ENT, Balic A. Do eosinophils have a role in the killing of helminth parasites? Parasitol Today 2000; 16(3): 95-101. http://dx.doi. org/10.1016/S0169-4758(99)01607-5. PMid:10689327.

Melby PC, Chandrasekar B, Zhao W, Coe JE. The hamster as a model of human visceral leishmaniasis: progressive disease and impaired generation of nitric oxide in the face of a prominent Th1-like cytokine response. J Immunol 2001; 166(3): 1912-1920. http://dx.doi.org/10.4049/ jimmunol.166.3.1912. PMid:11160239.

Mesquita D Jr, Araújo JAP, Catelan TTT, Souza AWS, Silva NP, Andrade LEC, et al. Aspectos celulares e moleculares da inflamação. Rev Bras Reumatol 2008; 10: 66-81.

Moreira PRR, Franciscato DA, Rossit SM, Munari DP, Vasconcelos RO. Influence of apoptosis on liver and spleen resistance in dogs with visceral leishmaniosis. Rev Bras Parasitol Vet 2016; 25(3): 342-347. http://dx.doi. org/10.1590/S1984-29612016054. PMid:27580400.

Nagase H, Okugawa S, Ota Y, Yamaguchi M, Tomizawa H, Matsushima $\mathrm{K}$, et al. Expression and function of Toll-like receptors in eosinophils: activation by Toll-like receptor 7 ligand. J Immunol 2003; 171(8): 3977 3982. http://dx.doi.org/10.4049/jimmunol.171.8.3977. PMid:14530316.

Neves MF, Starke-Buzetti WA, Castro AMMG. Mast cell and eosinophils in the wall of the gut and eosinophils in the blood stream during Toxocara vitulorum infection of the water buffalo calves (Bubalus bubalis). Vet Parasitol 2003; 113(1): 59-72. http://dx.doi.org/10.1016/S03044017(03)00037-2. PMid:12651217.

Oliveira TMFS, Furuta PI, Carvalho D, Machado RZ. A study of cross-reactivity in serum samples from dogs positive for Leishmania sp., Babesia canis and Ehrlichia canis in enzyme-linked immunosorbent assay and indirect fluorescent antibody test. Rev Bras Parasitol Vet 2008; 17(1): 7-11. http://dx.doi.org/10.1590/S1984-29612008000100002. PMid:18554433.

Pearson RD, Steigbigel RT. Phagocytosis and killing of the protozoan Leishmania donovani by human polymorphonuclear leukocytes. J Immunol 1981; 127(4): 1438-1443. PMid:7276565.

Pinto AJ, Figueiredo MM, Silva FL, Martins T, Michalick MS, Tafuri WL, et al. Histopathological and parasitological study of the gastrointestinal tract of dogs naturally infected with Leishmania infantum. Acta Vet Scand 2011; 53(1): 67. http://dx.doi.org/10.1186/1751-0147-53-67. PMid:22166041.

Plevraki K, Rallis TS, Adamama-Moraitou KK, Tontis D, Kritsepi M, Koytinas AF. Asymptomatic colitis in naturally infected dogs with Leishmania infantum: A prospective study. Am JTrop Med Hyg 2007; 76(1): 53-57. http://dx.doi.org/10.4269/ajtmh.2007.76.53. PMid:17255229.

Porrozzi R, Pereira MS, Teva A, Volpini AC, Pinto MA, Marchevsky RS, et al. Leishmania infantum-induced primary and challenge infections in rhesus monkeys (Macaca mulatta): a primate model for visceral leishmaniasis. Trans R Soc Trop Med Hyg 2006; 100(10): 926-937. http:// dx.doi.org/10.1016/j.trstmh.2005.11.005. PMid:16455120.

Queiroz NM, Assis J, Oliveira TM, Machado RZ, Nunes CM, Starke-Buzetti WA. Canine visceral leishmaniasis diagnosis by immunohistochemistry and PCR in skin tissues in association with RIFI and ELISA-test. Rev Bras Parasitol Vet 2010; 19(1): 32-38. http://dx.doi.org/10.1590/S198429612010000100007 . PMid:20385057.
Queiroz NM, Silveira RC, Noronha AC Jr, Oliveira TM, Machado RZ, Starke-Buzetti WA. Detection of Leishmania (L.) chagasi in canine skin. Vet Parasitol 2011; 178(1-2): 1-8. http://dx.doi.org/10.1016/j. vetpar.2010.12.033. PMid:21295916.

$\mathrm{R}$ Core Team. $R$ : a language and enviroment for statistical computing [online]. Vienna: R Foundation for Statistical Computing; 2018 [cited 2018 April 2]. Available from: http://www.R-project.org/

Reiner NE, Ng W, McMaster WR. Parasite-acessory cell interactions in murine leishmaniasis. II. Leishmania donovani suppresses macrophage expression of calss I and class II major histocompatility complex gene products. J Immunol 1987; 138(6): 1926-1932. PMid:2434567.

Rodrigues V Jr, Santana da Silva J, Campos-Neto A. Transforming growth factor beta and immunosuppression in experimental visceral leishmaniasis. Infect Immun 1998; 66(3): 1233-1236. PMid:9488418.

Rodrigues-Junior V, Silva JS, Campos-Neto A. Selective inability of spleen antigen presenting cells from Leishmania donovani infected hamsters to mediate specific T cell proliferation to parasite antigens. Parasite Immunol 1992; 14(1): 49-58. http://dx.doi.org/10.1111/j.1365-3024.1992. tb00005.x. PMid:1557230.

Ross R. Note on the bodies recently described by Leishman and Donovan. BMJ 1903; 2(2237): 1261-1262. http://dx.doi.org/10.1136/ bmj.2.2237.1261. PMid:20761169.

Silva DT, Neves MF, Queiroz NMGP, Spada JCP, Alves ML, Flóro e Silva M, et al. Correlation study and histopathological description of intestinal alterations in dogs infected with Leishmania infantum. Rev Bras Parasitol Vet 2016; 25(1): 24-36. http://dx.doi.org/10.1590/S198429612016009. PMid:26982556.

Silva FL, Tafuri WL, Oliveira MR, Tafuri WL. Histopathological and immunohistochemical study of the gastrointestinal tract from a dog naturally infected with Leishmania (Leishmania) chagasi: a case report. Arq Bras Med Vet Zootec 2002; 54(4): 340-344. http://dx.doi.org/10.1590/ S0102-09352002000400002.

Simecka J. Mucosal immunity of the gastrointestinal tract and oral tolerance. Adv Drug Deliv Rev 1998; 34(2-3): 235-259.

Tafuri WL, Oliveira MR, Melo MN, Tafuri WL. Canine visceral leishmaniosis: A remarkable histopathological picture of one case reported from Brazil. Vet Parasitol 2001; 96(3): 203-212. PMid:11240094.

Tafuri WL, Santos RL, Arantes RM, Gonçalves R, Melo MN, Michalick MS, et al. An alternative immunohistochemical method for detecting Leishmania amastigotes in paraffin-embedded canine tissues. J Immunol Methods 2004; 292(1-2): 17-23. http://dx.doi.org/10.1016/j.jim.2004.05.009. PMid:15350508.

Toplu N, Aydogan A. An immunohistochemical study in cases with usual and unusual clinicopathological findings of canine visceral leishmaniosis. Parasitol Res 2011; 109(4): 1051-1057. http://dx.doi.org/10.1007/ s00436-011-2345-0. PMid:21479577.

von Stebut E, Metz M, Milon G, Knop J, Maurer M. Early macrophage influx to sites of cutaneous granuloma formation is dependent on MIP$1 \alpha / \beta$ released from neutrophils recruited by mast cell-derived TNF $\alpha$. Blood 2003; 101(1): 210-215. http://dx.doi.org/10.1182/blood-2002-03-0921. PMid:12393677.

Wershil BK, Theodos CM, Galli SJ, Titus RG. Mast cells augment lesion size and persistence during experimental Leishmania major infection in the mouse. J Immunol 1994; 152(9): 4563-4571. PMid:8157970. 